\title{
T'oung Pao
}

\section{International Fournal of Chinese Studies}

\section{Edited by P.-E. Will (College de France, Paris, France) and W.L. Idema (Leiden University, The Netherlands)}

T'oung Pao is the foremost journal on Sinology. It aims at furthering our knowledge of traditional Chinese civilization. It covers history, literature, art, history of science, in fact almost anything that concerns China. Having celebrated its hundredth anniversary in 1990 , T'oung Pao has established itself as an unrivalled resource for the subject both in the major research libraries of the world and in the private libraries of professors, scholars and students of sinology. T'oung Pao offers you an easy way to stay on top of your discipline.

T'oung Pao contains articles predominantly in English with a few written in French or German. An abundance of figures and tables are included for clarification of details and ease of reading. Each issue of T'oung Pao comprises an extensive Book Review section keeping you up-to-date with all the latest information in the field of sinology.

- 1996. 2 double issues per year. (opprox. 384 pp. per volume)

- NLG 172.-UUS\$11.-

- Introductory rate: NLG 149._US\$ 97.-

- Postage and packing NLG 15.-IUS\$ 8.-

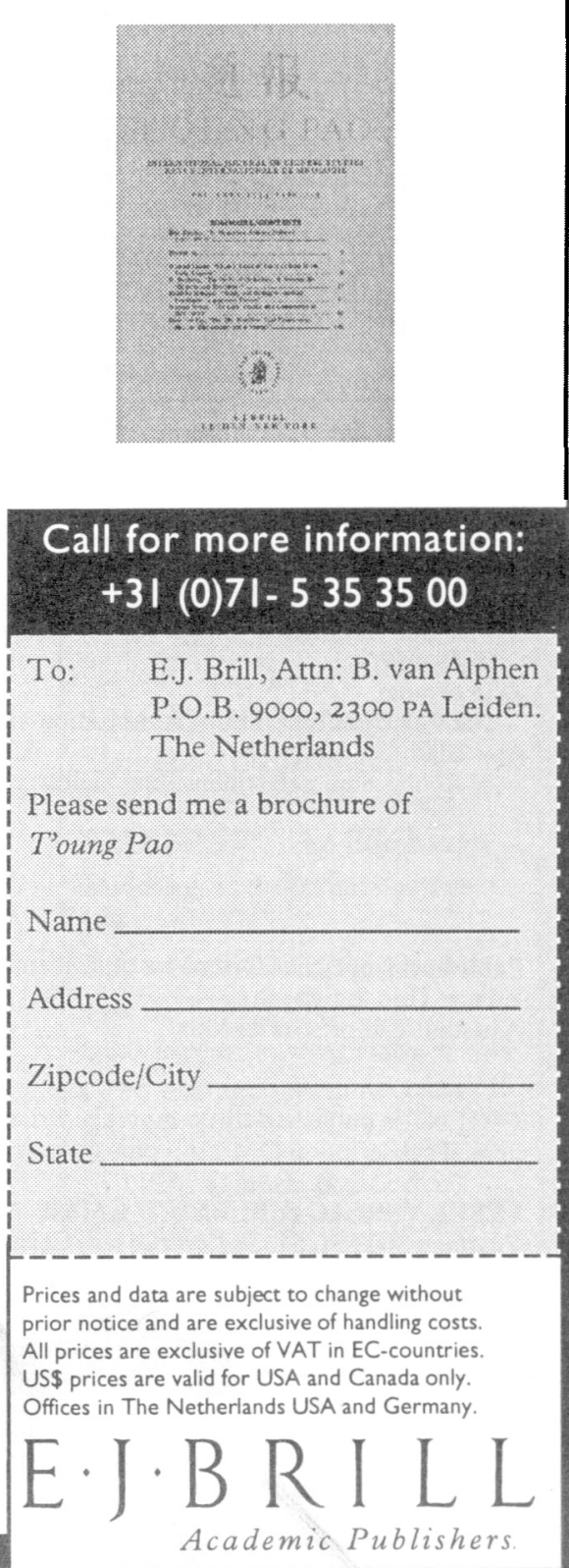




\section{O R I E N T}

\section{German Journal for Politics and Economics of the Middle East}

ORIENT is the only magazine in the Federal Republic of Germany dealing with the contemporary Near and Middle East (i.e. Arab States, Israel, Turkey, Iran, Afghanistan, Pakistan), as well as with modern oriental studies.

CONTENTS: Scientific articles, analyses, background reports and important documents, regular book reviews, detailed bibliographies of recent international publications with annotations, short biographies of leading oriental personalities.

\section{ORIENT 1/1995}

Michel G. Nehme

The shifting sands of political participation in Saudi Arabia

Winfried Manig

Institutional adjustment processes in rural regions - the case of Northwest Pakistan

Kai Hafez

Von der nationalen Frage zur Systempolitk: Perioden der DDR-Nahostpolitik, 1949-1989

Ziad Mouna

The Palestine Liberation Organisation and the German Democratic Republic

Ami Elad

Al-Kâtib - eine palästinensische Kulturzeitschrift als Forum der intifâda-Literatur

Publisher: Deutsches Orient-Institut, Hamburg

Editor: Udo Steinbach

Assistant Editor: Gerda Max

ORIENT is published three-monthly. Price per issue DM 35,-, annual subscription DM 116,- plus postage

\section{LESKE VERLAG \& BUDRICH GMBH}

Postfach 300 551, 51334 Leverkusen/Germany 


\section{Journal of the Royal Asiatic Society}

Editor: D. O. Morgan,

School of Oriental and African Studies, University of London

Published for the Royal Asiatic Society of Great Britain and Ireland

JRAS is a journal distinguished not only by its longevity but also by its consistent aim of providing a forum for scholarly articles of the highest quality on all aspects of the Indian Subcontinent, the Middle East, Central Asia, the Far East and South East Asia. Articles in the journal always make a genuine contribution to scholarship, but at the same time they are accessible to an exceptionally wide range of readers - specialists and researchers, professionals and general readers.

\section{Forthcoming articles}

Meetings with Maji: Iranian themes among the Greeks, from Xanthus of Lydia to Plato's Academy

\section{Peter Kingsley}

The Ardhakathanaka by Banarasi Das: a Socio-cultural study

Eugenia Vanina

Love, poetry and renunciation: changing configurations of the ideal of suki Rajyashree Pandey

\section{Subscription}

Journal of the Royal Asiatic Society is published three times a year, in April, July and November. Volume 5 , in 1995: f49 for institutions; $\mathbf{} 32$ for individuals. Airmail 114.50 per year extra.

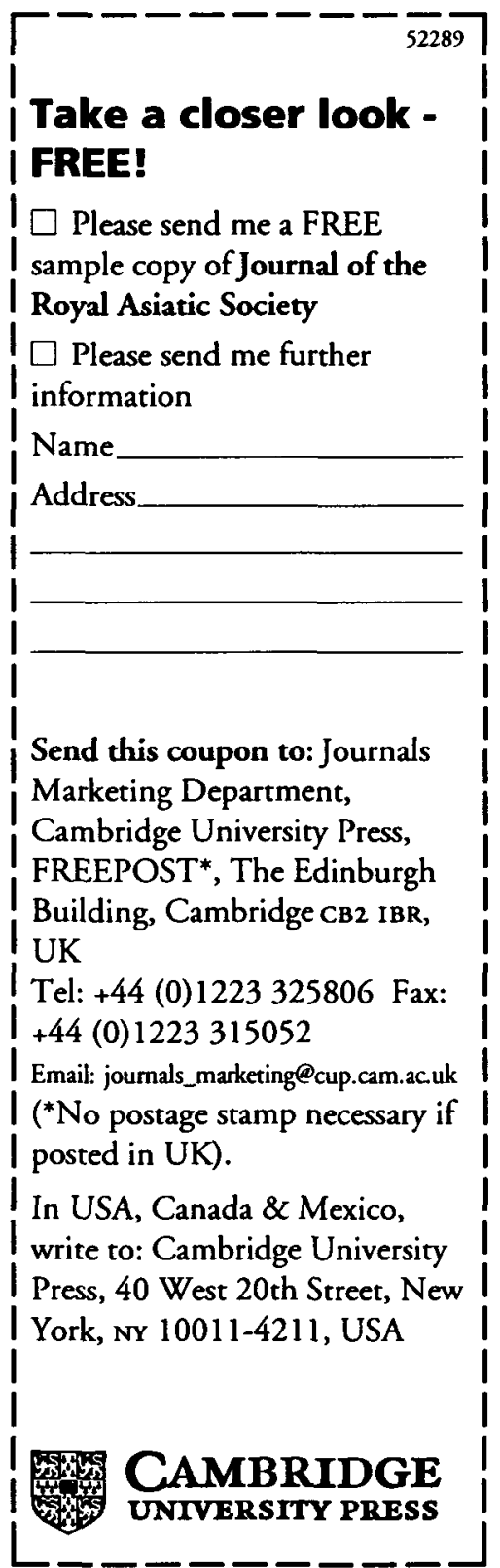




\section{O R I E N T}

\section{German Journal for Politics and Economics of the Middle East}

ORIENT is the only magazine in the Federal Republic of Germany dealing with the contemporary Near and Middle East (i.e. Arab States, Israel, Turkey, Iran, Afghanistan, Pakistan), as well as with modern oriental studies.

CONTENTS: Scientific articles, analyses, background reports and important documents, regular book reviews, detailed bibliographies of recent international publications with annotations, short biographies of leading oriental personalities.

\section{ORIENT 3/1995}

\section{Munir D. Ahmed und Kai Hafez}

Das Orient- und Islambild in Deutschland. Überlegungen zum Friedenspreis des Deutschen Buchhandels und ein Gespräch mit Annemarie Schimmel Andreas Rieck

Sectarianism as a political problem in Pakistan: The case of the Northern Areas Wilfried Buchta

Die Islamische Republik Iran und die religiös-politische Kontroverse um die marja'tyat

Abdolah Hoveyes

Ein Beitrag zur politischen und kulturellen Lage der arabischen Minderheit in Iran

Eyal Zisser

Syria and Israel: from war to peace

Igor Lipovsky

The Russian problem in Central Asia

Helmuth Toepfer

Zur Investitionsbereitschaft türkischer Remigranten

Publisher: Deutsches Orient-Institut, Hamburg

Editor: Udo Steinbach

Assistant Editor: Gerda Max

ORIENT is published three-monthly. Price per issue DM 35,-, annual subscription DM 116,- plus postage

\section{LESKE VERLAG \& BUDRICH GMBH}

Postfach 300 551, 51334 Leverkusen/Germany 
African Affairs was founded in $\mathbf{1 9 0 1}$ to commemorate and continue the work of Mary Kingsley on the study of Africa. Each issue contains five or six original articles on modern history, and social, economic and political developments. The articles reflect these disciplines and all regions of Africa, ensuring something of interest for most Africanists.

\section{Recent and forthcoming articles}

\section{Vladimir Shubin}

The Soviet Union/Russian Federation's Relations with South Africa with Special Reference to the Period since 1980

\section{Wiseman Chirwa}

Fishing Rights and Fears of Ecological Degradation along Southern Lake Malawi, 1920-64

\section{Joseph Ayee}

The Measurement of Decentralization: the Ghanaian Experience 1988-92

\section{Kweku Ampiah}

Japanese Aid to Africa: a Study of the Political Marketing of Japan in Africa

\section{Roger Gocking}

Ghana's Public Tribunals: an Experiment in Revolutionary Justice

\section{David Simon}

Restructuring the Local State in PostApartheid Cities: Namibian Experience and Lessons for South Africa

\section{Douglas Anglin}

International Monitoring of the South African Elections

\section{Gisela Geisler}

Troubled Sisterhood: Women and Politics in Soúthern Africa

\section{Tom Lodge}

The South African Elections of 1994

\section{African Affairs}

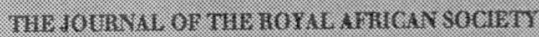

Volume $93 ; 1956$

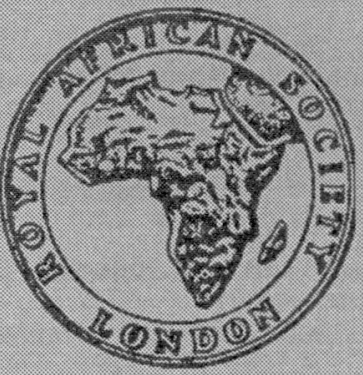

ORDER FORM 1996

Please enter my subscription to: AFRICAN AFFAIRS

Subscription rate Volume 95 ( 4 issues)

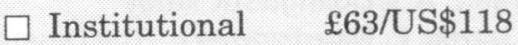

$\square$ Individual $£ 36 /$ US $\$ 60$

Please note: $\mathcal{E}$ Sterling rate applies in Europe, US\$ rate elsewhere, and that customers in the EU, and in Canada, are subject to their local sales tax.

Name.

Address.

City/County

Postcode.

$\square$ I enclose the correct remittance.

Please debit my American Express/ Diners/Mastercard/Visa/JCB Card Number

Expiry Date

For further subscription information please write to: Journals Marketing (X96), JPVA

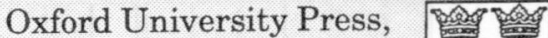
Walton Street, Oxford, OX2 6DP, UK.

Fax:(+44) (0) 1865267485 


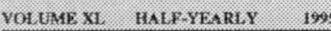

JOURNAL, OF SEMITIC STUDIES

LDHORHL COMMITHE

P. S. Alecander, C. J. Brocke, J.F. Heatey, P. C. Sartenove, G. Rex Sintit

OXFORD UNIVIERSTI Y PRESS
The Joumal of Semitic Studies was established in 1955 and since then has built up a reputation as one of the leading international academic journals in its field. 'Semitic Studies' has always been understood by the editors of the Journal to include the modern as well as the ancient Near (Middle) East, with its special emphasis on research into the languages and literatures of the area. The editors, based in the Department of Middle Eastern Studies at the University of Manchester, continue to maintain the policy of ensuring that each volume contains items of interest to Orientalists and Biblical Scholars. Extensive reviews of selected new books, as well as general review notices, remain a feature of the Journal. Recent and forthcoming articles include:

- Nigel Allan Catalogue of Hebrew Printed Books (1491-1900) in the Wellcome Institute, London

- Solaiman Al-Theeb Two New Dated Nabataean Inscriptions from al-Jawf

- Klaus Beyer Die Aussprache des Christlich-Palästinischen Aramãisch: zur Neuen Grammatik von Christa Müller-Kessler

- S. P. Brock Mingana syr. 628: a Folio from a Revision of the Peshitta Song of Songs - George J. Brooke 4Q253: A Preliminary Edition

-W. J. Donaldson Units of Counting and Aggregation in Omani Arabic

- Amikam Gai The Category 'Adjective' in Semitic Languages

- Clive Holes The Structure and Function of Parallelism and Repetition in Spoken Arabic: A Sociolinguistic Study

- James E. Montgomery The Deserted Encampment in Ancient Arabic Poetry: A Nexus of Topical Comparisons

- David Thomas The Miracles of Jesus in Early Islamic Polemic

The Journal of Semitic Studies publishes a Supplement Series of hardback books which are available separately from the subscription to the Journal. Recent and forthcoming titles in this series include:

Sinasi Gand0z The Knowledge of Life: The Origins and Early History of the Mandaeans and Their Relation to the Sabians of the Qur'an and to the Harranians (ISBN: 0199221936 ) Andrey Korotayev Ancient Yemen: Some General Trends of Evolution of the Sabaic Language and Sabaean Culture (ISBN: 019922237 1)

J. C. Greenfield, M. J. Geller, M. P. Weitzman (eds.) Studia Aramaica: New Sources and New Approaches (ISBN: 019922194 4)

Supplement Series books are available from Barbara Darling, Journals Marketing, Oxford University Press.

\section{ORDER FORM $\square$ Please enter my subscription to the Journal of Semitic Studies}

Volume 41 (two issues): $\square$ Institutions $£ 64 /$ US\$120 $\square$ Individuals $£ 42 / U 5 \$ 78$

Subscribers in developing countries may subscribe to the Journal of Semitic Studies at the reduced rate of US $\$ 75$. Please note: $f$ sterling rates apply in Europe, US\$ rates elsewhere. Customers in the EU and in Canada are subject to their local sales tax.

$\square$ I enclose the correct remittance.

Name Address

City/County.

Postcode

Please debit my Mastercard/Diners/American Express/Visa/JCB Card number:

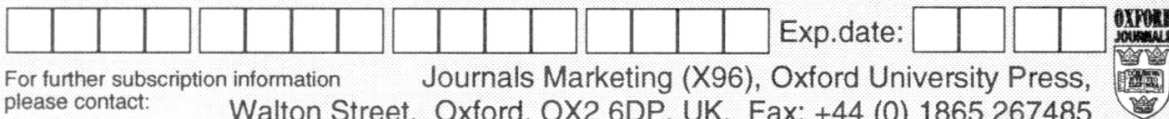

